\title{
Economic Processes and Social Results of Digitalization of the Educational Sphere
}

\author{
Afanasyeva T.S. \\ Saint Petersburg University \\ of Management Technologies and Economics, \\ Saint Petersburg, Russia, \\ tafanfasy@yandex.ru \\ Fetisova G.V. \\ Yaroslav-the-Wise Novgorod State University, \\ Russia, Veliky Novgorod, \\ galina.fetisova@novsu.ru
}

\author{
Ilyina I.A. \\ Saint Petersburg Electrotechnical University “LETI”, \\ Saint Petersburg, Russia, \\ inka4@yandex.ru \\ Pokrovskaia N.N. \\ Herzen State Pedagogical University of Russia, \\ Saint Petersburg, Russia, \\ Peter the Great St. Petersburg Polytechnic University, \\ Saint Petersburg, Russia, \\ Saint Petersburg Electrotechnical University "LETI", \\ Saint Petersburg, Russia, \\ nnp@spbstu.ru,nnp@herzen.spb.ru
}

\begin{abstract}
The relevance of the problem under study is due to a change in the structure of modern education as a result of the integration of new information technologies and the introduction of the web economy. These external challenges are transforming the educational sphere and significantly changing the situation on the profession market, increasing the demand for highly qualified specialists, which leads to the need to change education standards, identify needs in accordance with new realities and in the formation of competencies that meet these challenges. This means that, on the one hand, established traditions and methodological foundations are undermined, and on the other hand, education is moving to a new qualitative level: the process of disseminating knowledge is accelerating, opportunities for interactive interaction with the content provided are expanding and access to information is simplified. Within the framework of the article, the process of digitalization of the educational environment is considered, the foreign and Russian experience of informatization of education is studied, the current state of the educational sphere is analyzed and recommendations for the purposeful design of an environmentally friendly educational system are developed. The convergence of the educational environment and the digital field, focused on increasing productivity and meeting human needs, allows one to form a new approach to education. Note that in Russia a significant number of educational institutions are not ready for the introduction of digital technologies and the active use of virtual communications. The materials of the article are of practical value for the introduction of digital technologies both at the level of individual educational structures and in the educational sphere as a whole.
\end{abstract}

Keywords—education, digital university, sustainable education

\section{INTRODUCTION}

The latest discoveries in science, technology development, new directions of social development - all this is impossible without a primary, fundamental basis in the form of education. Therefore, serious requirements are imposed on the education system. On the one hand, the active use of new technologies becomes determinative in the functioning and implementation of communications and business processes. On the other hand, the level of digital adaptation of the educational sphere, despite the active implementation of programs of state support for digitalization, is still at the stage of formation.

The topic of digitalization of the educational environment has been quite actively discussed in scientific circles in recent years, and even that small part of the research that we use in this work to demonstrate the specifics of transformations in the educational sphere proves the ever-increasing relevance of this issue [1-6]. At the same time, experts determine the level of the EdTech market in different ways (from the English Educational technology). The global education market in 2019 amounted to about $\$ 6$ trillion, of which the digital part, according to the international analytical agency HolonIQ, is just over $1 \%$, or $\$ 74$ billion.

The overall dynamics of the development of Russian education is negative, due to the reduction of most types of educational organizations through optimization and merger, also due to an increase in the cost of education. According to the Federal State Statistics Service [7], higher education in Russia rose by $15 \%$ in 2019 , which indicates an increased interest in improving professional activities and implementing a competency-based approach. 
There are a number of misconceptions about the digitalization of education. Firstly, digitalization is being realized due to the change of media from traditional paper to electronic, but otherwise everything happens unchanged. Secondly, the digital organization of learning is the automation of processes thanks to technology. That is, the speed of information transfer simply increases and the volume of information flows increases. Thirdly, there is the possibility of extending the educational environment to a wide audience.

Of course, the impact of digitalization on educational services is great. In this case, we must talk about a fundamentally new approach to the implementation of activities. Of course, when moving into the digital field, any digital company works with digital technologies, exists in the digital space and creates this digital environment. That is, formally there is a change of carriers, but, in fact, the structure of the service and its consumer are changing. This became especially evident during the pandemic, when educational services became a relevant resource, and the sphere itself turned into a stream of online projects of various levels, quality and complexity.

And, it is quite obvious that this does not correspond to the parameters originally laid down in the concept of education. For universities, digitalization is also a challenge that requires certain efforts to resolve issues. And if large universities are in a more advantageous position, since they have financial resources, but sometimes do not fully realize their important leadership role in the implementation of innovative solutions based on digital technologies, then small universities suffer from a lack of funding, qualified personnel and employees able to quickly adapt to new realities, but they react to changes more actively.

\section{RESEARCH QUESTIONS}

3.1 What resources does Russia have in the transition to the digital field?

3.2 What are the negative obstacles to the transition of the Russian Federation to the digitalization of the socio-economic space?

3.3 How does the digitalization of education improve in the time of sustainable development?

3.4 What are the prospects for using digital technologies in the Russian Federation in the formation of a digital ecosystem?

\section{PURPOSE OF THE STUDY}

The purpose of the study is to study the impact of the convergence of digital infrastructure and education on social and economic processes and develop recommendations for the design of the educational ecosystem.

\section{RESEARCH METHODS}

The work used economic and mathematical, structural and logical research methods, analytical processing of various documents, regulations, decrees and laws was carried out. In this paper, for further statistical analysis, the organization of the process of collecting and processing data is proposed. The use of survey methods made it possible to study and conduct a sociological study of the dynamics of the formation of public opinion regarding the digitalization of the educational sphere.

\section{PROBLEM STATEMENT}

The sphere of education in Russia is rapidly developing and changing, turning from a static conservative system into a competitive service sector, where all activities are subject to the rules and conditions of a market economy. The priority direction of the state's development is the digitalization of the economic sphere, which determines the ways of development of the education sphere [8,9].

The digitalization of the economy, the development of information and communication technologies and humanmachine interfaces, the introduction of neural networks and Big Data technology, the use of machine learning and artificial intelligence as a result of the implementation of the strategic plan for the development of German industry began to be actively implemented in the global socio-economic space [10-14].

The role of a country in the international arena of the division of labor, as well as its competitiveness in various industries, depends on the level and quality of training of specialists and the conditions created by the state for the implementation of the intellectual knowledge of the population. Today, education has become a service that characterizes the transfer of specific information from one person to another on certain conditions. And often the supply exceeds the demand: in addition to traditional educational institutions (schools, technical schools, colleges, universities), more and more often in the educational services market one can find private companies providing short-term educational services for which they are not licensed, which increases competition in this market. One must not forget that advertising and its tools are the main stimulating factor in the sale of services.

One of the indicators of an effective communication policy of a company and the level of its digitalization is considered representation in the electronic environment and active work in the digital space. The activation of the company's information field in the digital space can serve as an indicator of the level of involvement in the information agenda, which means competitiveness in the new digital environment.

Therefore, the positioning of universities in the digital environment is an important part of building competitiveness. Analysis of the information space showed an increase in the interests of universities in the topic of digitalization. The media publications were monitored on the Medialogia platform [15]. If until 2019 the bulk of information messages were scientific publications, then over the past year there has been a significant leap in the increase in the number of publications in the media, which means that the positioning of the importance of digitalization of universities for the mass audience has become more active (Fig. 1.).

Less than 10 years ago, the issues of digitalization of universities were more of a theoretical problem. The catalyst for understanding the level of digitalization of education was the situation of the COVID-19 pandemic. The need for an instant transition to the digital space due to the impossibility of working in an offline environment revealed a number of factors that make it possible to talk about the competitiveness of educational structures in the new conditions of existence. Monitoring social media by tone and nature of publications allows not only to identify the attitude towards this issue, but also to understand the existing problems in this area. The use of monitoring and text analyzers allows obtaining more accurate 
results than sociological surveys, since the resulting data array shows the dynamics of the development of this issue in real time.

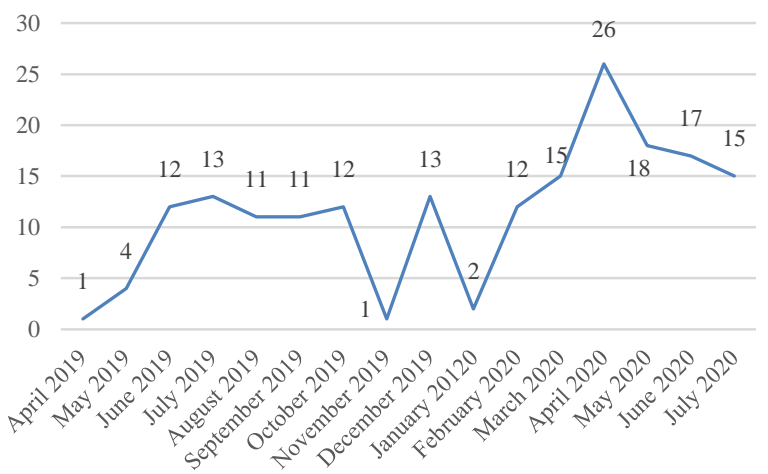

Source: Monitoring on the Medialogia platform [15]

Fig. 1. Quantitative dynamics of media publications on the topic of digitalization of the educational environment

In theory, digitalization was seen as expanding the capabilities of the educational environment for training specialists of almost any profile and orientation. In practice, it became clear that not every university was fully aware of the possible obstacles in relation to the training of specific specialists.

Education during the period of self-isolation showed that it was digital communications that turned out to be the most acceptable for learning, but at the same time it is also the weakest link in the educational process. By early March 2020, all educational institutions in Russia were forced to move to digital space.

The activity of introducing the leading universities of St. Petersburg into the digital space, included in the Top 100 program, is shown in the figure (Fig. 2).

We drew attention to the fact that there is an increase in the activity of working with the audience. The share of negative publications has significantly decreased over the period (March-June 2020) in comparison with the quantitative indicators of the sentiment of publications for the same period of time (March-June 2019). This is due to the activation of universities in working with comments and negative messages on the Internet. The undisputed leader in shaping the agenda is St. Petersburg State University (Fig. 3.).

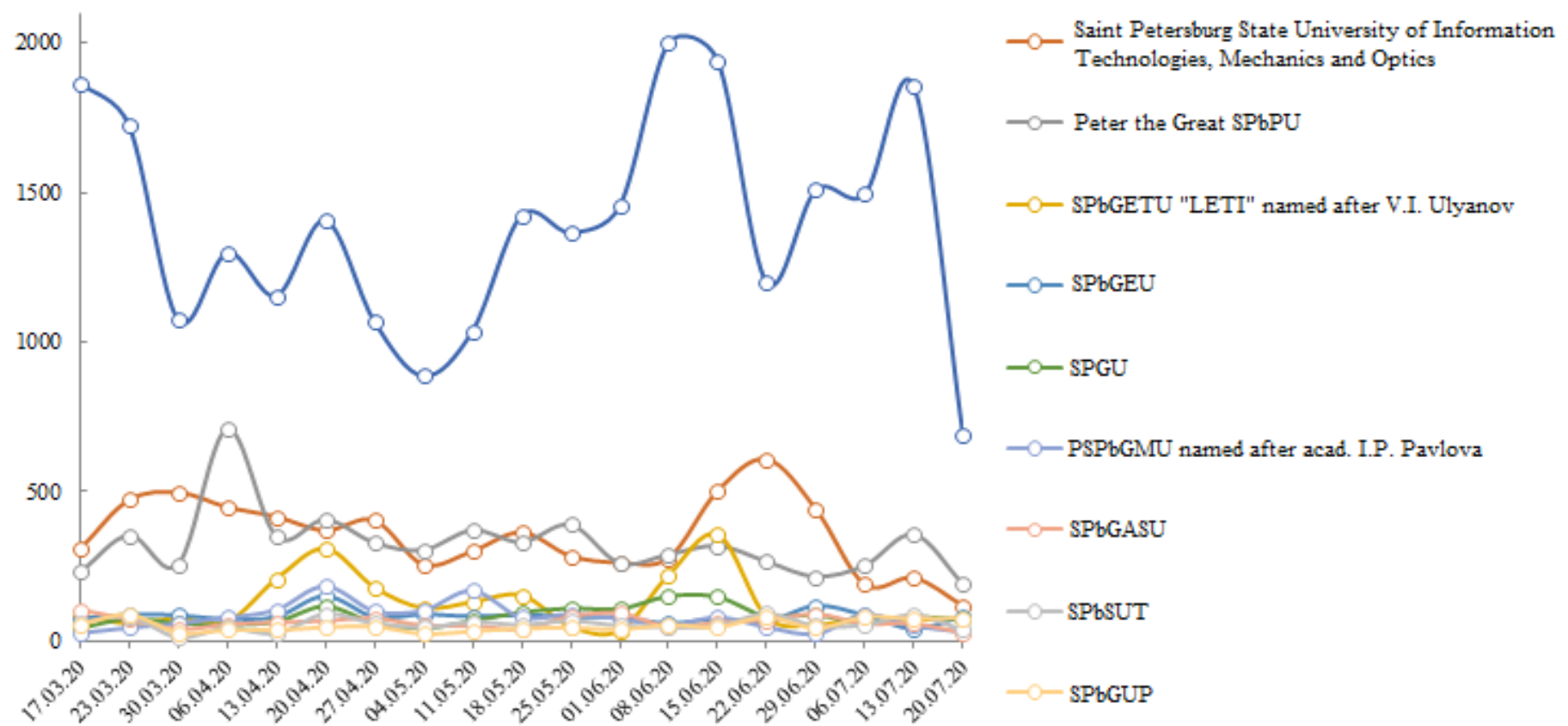

Fig. 2. Publication activity of universities during the active phase of distance work

The concept of ecological systems has long gone beyond the scope of use exclusively in the field of ecology and is associated with the description of the stability and self-sufficiency of any complex self-organizing, self-regulating and self-developing system. Total digitalization has spawned a "digital ecosystem", which implies the presence of a data transmission platform and infrastructure based on social, economic, political, psychological factors [16-19].

The digitalization of social processes was first discussed at the end of the 20th century. In the new digital reality, an important component of the educational environment is not so much a continuous educational process as the empowerment of gadgets and network integrators (platforms that provide communication and communication) and access to digital library materials.

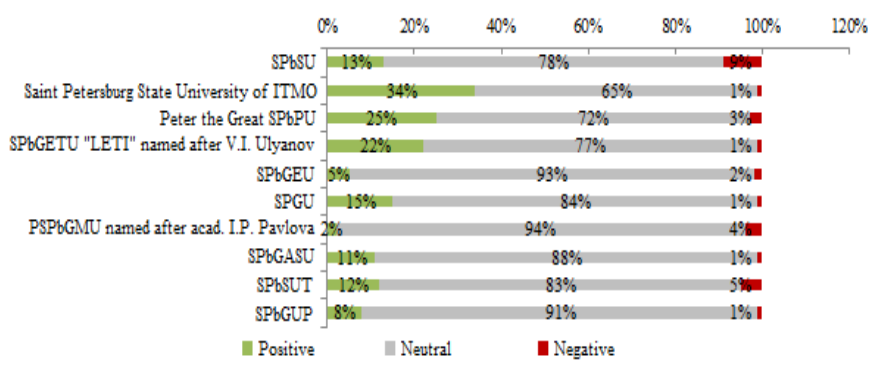

Fig. 3. Tonality of publications in the media and social networks 
More important problems, in our opinion, are the formation of skills for self-organization and planning of one's own time and the formation of competencies in the field of information and computer literacy. This is the ideal option, which in theory was a great alternative to offline learning.

As negative consequences, a significant decrease in the level of socialization of a person, a violation of orthobioticity and a lack of focus on health-saving technologies should be noted.

\section{FINDINGS}

The educational sphere at this stage of development is not ready for total digitalization and the active use of digital technologies and virtual communications. In addition, even the level of digitalization itself in Russian universities is very different. Universities strive to build up these competencies and pool resources to improve competitiveness. However, there are still no uniform standards for connecting data and services, and this seriously hinders development. An important factor in the development of the educational eco-environment is the formation of a global educational space that can not only introduce digitalization and implement the educational process in the virtual information field, but also form a cluster of the educational environment that can integrate into new realities and allow raising the cultural and educational level at a new level. Existing platforms that accumulate knowledge of not one specific university, but the best examples of educational content (https://ru.coursera.org, https://www.lektorium.tv, https://stepik.org/catalog, https://arzamas.academy, https://universarium.org, https://www.edx.org, https://postnauka.ru), have already proven themselves quite well and allow realizing a high level of audience engagement with high quality material, which is serious competition for offline education. Therefore, universities need to increase the potential for virtualizing their own educational environment.

\section{CONCLUSION}

To design an environmentally friendly educational system based on improving the policy of interaction between the digital space and the educational environment, focused on increasing productivity, meeting new human needs, several points must be taken into account. On the one hand, this concerns directly the structure of the educational system, where the teaching technology should be based on a variety of content and forms of the educational process:

- providing access to online materials for all students, using digital libraries, creating distance universities;

- providing access to online resources of leading Russian universities in order to increase the efficiency of independent work;

- supplementing traditional educational technologies with distance learning;

- introduction of an interactive learning system with the active use of multimedia technologies with the possibility of student and teacher feedback;

- adaptation of the discipline read to the realities of society, to socio-economic changes;

- improving the management of information flows and knowledge in digital ecosystems (increasing the amount of non-formalized knowledge, an appeal to empirical data and practical results of work);

- development of project activities (In accordance with FSES $3+$ and FSES $3++$ ).

In addition, to integrate the system of universities into the industrial concept "Industry 4.0", it is necessary to use the PLM (Product Lifecycle Management) system for structuring the data array and automating the management of physical and information processes, Big Data technology for managing information-intensive processes of the educational system, Smart Factory (analogue of the German the term Intelligente Fabrik), CPS for the formation of the infrastructure of the Internet of things. And it is not informatization, that is, the speed of information transfer, that should come to the fore, but the use of integrated approaches to the educational system when individualizing learning trajectories. That is, it is necessary to transform the education system into an educational ecosystem, where early development programs aimed at schoolchildren, an inclusive educational trajectory for people with disabilities and a lifelong learning system for adults based on the flipped learning approach can coexist.

\section{Acknowledgment}

The research was carried out within the framework of the grant project No 16-29-12965\18 with financial support from the Russian Foundation for Basic Research.

\section{References}

[1] C.E. Tømte, T. Fossland, P.O. Aamodt, and L. Degn, "Digitalisation in higher education: mapping institutional approaches for teaching and learning", Quality in Higher Education, 2019, vol. 25(1), pp. 98-114. DOI: 10.1080/13538322.2019.1603611

[2] V.N. Minina, "Digitalization of higher education and its social outcomes", Vestnik of Saint Petersburg University. Sociology, 2020, vol. 13(1), pp. 84-101. (In Russ.). DOI: https://doi.org/10.21638/spbu12.2020.106

[3] Difficulties and prospects of digital transformation [Trudnosti i perspektivy tsifrovoy transformatsii obrazovaniya], In Ed. by A.Yu. Uvarov, I.D. Frumin, Moscow: Higher School of Economics Publishing House, 2019, 343 p. (In Russ.).

[4] M. Bond, K. Buntins, S. Bedenlier, O. Zawacki-Richter, and M. Kerres, "Mapping research in student engagement and educational technology in higher education: a systematic evidence map", International Journal of Educational Technology in Higher Education, 2020, vol. 17, article 2.

[5] M. Bond, "Facilitating student engagement through the flipped learning approach in K-12: A systematic review", Computers \& Education, 2020, vol. 151, 103819. DOI: https://doi.org/10.1016/j.compedu.2020.103819

[6] O. Zawacki-Richter, V.I. Marín, M. Bond, and F. Gouverneur, "Systematic review of research on artificial intelligence applications in higher education - where are the educators?", International Journal of Educational Technology in Higher Education, 2019, vol. 16, article 39. DOI: $10.1186 / \mathrm{s} 41239-019-0171-0$

[7] Federal State Statistics Service of the Russian Federation, 2020. (In Russ.). Retrieved from https://rosstat.gov.ru/

[8] Decree of the President of the Russian Federation of May 9, 2017 No 203 "On the Strategy for the Development of the Information Society in the Russian Federation for 2017-2030" ["O Strategii razvitiya informatsionnogo obshchestva v Rossiyskoy Federatsii na 2017-2030 gody"], 2017. (In Russ.). Retrieved from www.kremlin.ru/acts/bank/41919

[9] Order of the Government of the Russian Federation of July 28, 2017 No 1632-r "On the approval of the programme "Digital economy of the Russian Federation" ["Ob utverzhdenii programmy "Tsifrovaia ekonomika Rossiiskoi Federatsii”], 2017. (In Russ.). Retrieved from http://government.ru/docs/28653/

[10] J.J.M. Ferreira, C.I. Fernandes, and F.A.F. Ferreira, "To be or not to be 
digital, that is the question: Firm innovation and performance", Journal of Business Research, 2018, vol. 101, pp. 583-590.

[11] C. Loebbecke, and A. Picot, "Reflections on societal and business model transformation arising from digitization and big data analytics: A research agenda", The Journal of Strategic Information Systems, 2015, vol. 24(3), pp. $149-157$.

[12] K. Schwab, The fourth industrial revolution [Die Vierte Industrielle Revolution], 2016. (In Germ.). Retrieved from https://www.deutschlandfunkkultur.de/klaus-schwab-die-vierteindustrielle-revolution-der.950.de.html?dram:article_id=361268

[13] D. Stokols, Social Ecology in the Digital Age. Solving Complex Problems in a Globalized World, Cambridge, MA: Academic Press, 2018, 399 p.

[14] E.V. Laar, A.J.A.M. van Deursen, J.V. Dijk, and J.D. Haan, "The relation between 21 st-century skills and digital skills: A systematic literature review", Computers in Human Behavior, 2017, vol. 72, pp. 577-588. DOI: https://doi.org/10.1016/j.chb.2017.03.010
[15] Medialogia, 2020. (In Russ.). Retrieved from https://www.mlg.ru

[16] E. Akhmetshin, I. Ilyina, T. Teor, and V. Kulibanova, "Special aspects of master data-based integrated management of region reputation in modern IT environment", In IOP Conference Series: Materials Science and Engineering, 2019, vol. 497(1), article 012022. DOI: 10.1088/1757899X/497/1/01202

[17] T.S. Afanasyeva, and N.I. Grishakina, "The use of representative systems as a means of teaching students", In The European Proceedings of Social and Behavioural Sciences, 2019, pp. 924-932. DOI: https://dx.doi.org/10.15405/epsbs.2019.04.100

[18] V.A. Grachev, "Ecology, digitization and atomic energy", Energy: Ecomomics, Technology, Ecology, 2020, vol. 6, pp. 35-43. (In Russ.).

[19] B.I. Tikhomirov, "Digital Transformations of Socio-Economic Development: A Thorny Path to a New Quality Information Society", Economics, taxes \& law, 2019, vol. 12(4), pp. 20-28. (In Russ.). DOI: 10.26794/1999-849X-2019-12-4-20-28 